\title{
Better to Forgive or to Forget? Marital Transgressions and Forgiveness in Older Couples
}

\author{
Jakob F. Jensen, $\mathrm{PhD}$ \\ East Carolina University, Greenville, North Carolina, United States \\ (iD https://orcid.org/0000-0003-0809-6943
}

\author{
Amy Rauer, $\mathrm{PhD}$ \\ University of Tennessee, Knoxville, Tennessee, United States \\ (iD https://orcid.org/0000-0002-4272-7641
}

Amanda L. Johnson, MS

Auburn University, Auburn, Alabama, United States

Contact: jensenja14@ecu.edu

\begin{abstract}
Navigating romantic transgressions in older adulthood is imperative for both relationship quality and longevity, making forgiveness a critical process. The current study examined marital transgressions and forgiveness among 64 older (age range $=56-89$ ), higher-functioning, primarily White, married couples studied at two time points spaced 16.4 months apart. More than half the spouses did not report a transgression in the past year, and not doing so was associated with better marital functioning at both time points. Of the transgressions reported, thematic analyses revealed they fell into six categories (e.g., spouse behaving badly, financial issues), but were overall relatively minor in nature. If husbands engaged in greater avoidance after a transgression, both spouses were less maritally satisfied a year later. Findings suggest more attention to not only forgiveness approaches employed (avoidance of the issue versus avoidance of the person) but also to the potential role of gender and timing in these associations.
\end{abstract}

Keywords: forgiveness, marital transgressions, older adulthood, marriage, marital satisfaction

Date Submitted: June 14, 2021 | Date Published: November 20, 2021

\section{Recommended Citation}

Jensen, J. F., Rauer, A., \& Johnson, A. L. (2021). Better to forgive or to forget? Marital transgressions and forgiveness in older couples. Journal of Social, Behavioral, and Health Sciences, 15(1), 293-308. https://doi.org/10.5590/JSBHS.2021.15.1.20

\section{Introduction}

Nearly all people will experience occasionally feeling wronged or hurt by a partner in a close relationship (Fincham et al., 2004). Although interpersonal conflicts can range in severity from minor differences in

We have no conflicts of interest to disclose. The research reported was funded by grants from the John E. Fetzer Institute and the Alabama Agricultural Experiment Station to the second author. We are grateful to the families of the Marriage and Retirement Study for their participation.

Correspondence concerning this article should be addressed to Jakob Jensen, Rivers West Bldg. RW134, East Carolina University, Greenville, NC 27858. Email: jensenja14@ecu.edu 
preferences to severe issues such as infidelity (Gordon \& Baucom, 1998), the common theme is that at least one partner perceives it as a transgression. Partners may be able to overlook minor conflicts, but transgressions perceived as more serious may require concerted efforts to preserve the relationship (e.g., metacommunication; Wilson \& Gottman, 2002). One of the most effective ways to handle transgressions is forgiveness, whereby an individual works to decrease negative emotions and increase positive emotions towards the transgressor (Braithwaite et al., 2011). A key piece of forgiveness is that it is a performative process (Gordon \& Baucom, 1998): an intentional, voluntary act that is likely repeated many times over the course of a relationship. Not surprisingly then, partners often cite forgiveness as critical to the success of their relationship (Fincham \& Beach, 2001), a conclusion supported by its array of documented benefits for relationship satisfaction and stability (Finkel et al., 2002; Fincham \& Beach, 2007).

Although forgiveness is seen as imperative to long-term marital success, much of the research has focused on those in less established relationships (McNulty, 2008; Molden \& Finkel, 2010). However, the performative process of forgiveness may operate differently after partners have enacted it repeatedly over decades, rather than a few months or years. Given the potential long-term costs of forgiveness (e.g., frequent forgiveness removing the transgressor's accountability; McNulty, 2008), taking a dyadic, developmental perspective may reveal whether forgiving and being forgiven is uniformly beneficial in enduring marriages. Moreover, it is likely that the nature of marital transgressions may change as well, potentially altering the forgiveness process. Thus, the current study utilized a multi-method approach with a sample of 64 higher-functioning, older married couples to explore the links between marital transgressions, forgiveness, and concurrent and future marital satisfaction. Identifying the nature of marital transgressions and how couples forgive each other later in life may yield important insights into how spouses could be encouraged to approach marital issues across the lifespan.

\section{Current Perspectives on Marital Transgressions and Forgiveness in Marriage}

Forgiveness is an ongoing action that the person who was hurt must continually process, one that is highly dependent on the severity of the transgression (Gordon \& Baucom, 1998). More severe transgressions (e.g., infidelity) tend to engender a more arduous and painful forgiveness process, whereas more minor transgressions (e.g., disagreements over preferences) often lend themselves to a smoother, easier process. Though the forgiveness process can be painful at times, partners who navigate it successfully derive relational benefits (Paleari et al., 2005). For example, McNulty (2008) found that younger newlyweds who behaved less negatively and engaged in more forgiveness were more satisfied and reported less severe marital problems. As to who is likely to forgive their partners, those more satisfied with and invested in their relationships are also more likely to engage in this relationship-enhancing process (Fincham \& Beach, 2007; Molden \& Finkel, 2010).

Although multiple motivations may drive forgiveness in marriage (Fincham et al., 2004; Ghaemmaghami et al., 2011), we focus here on the role of avoidance when forgiving. Fincham and colleagues (2004) describe avoidance as a more passive process whereby the spouse either avoids the transgressor or the hurt caused by the problem. It is important to note that although their scale only measures the former (e.g., "I withdrew from my partner"), avoiding the person versus avoiding the problem may represent two distinct types of motivation. Avoiding the person may convey current unwillingness to forgive the partner for the transgression. Avoiding the problem, in contrast, may indicate that the victim would rather overlook the transgression to maintain positivity in the relationship. Such a distinction may be particularly important to begin to explore when considering forgiveness in later-life marriages.

\section{Forgiveness in Later-Life Marriages}

The developmental changes that occur later in the lifespan, such as enhanced emotion regulation and decreased negativity (Charles, 2010; Charles \& Carstensen, 2007), may uniquely shape the forgiveness process and its effects in older couples. Socioemotional selectivity theory (SST; Carstensen, 1992) posits that as 
individuals age, they strategically work to maximize positivity and minimize negativity within their close relationships (Charles, 2010; Penningroth \& Scott, 2012), both critical pieces of the forgiveness process (Braithwaite et al., 2011). Even when older adults discuss areas of relational strife, they tend to reflect on the conversation more positively (Story et al., 2007), despite discussing negative content. Moreover, older adults not only avoid exposure to negative emotional experiences, but also recommend doing so to others as a way to augment positivity in their remaining years (Charles, 2010; Charles et al., 2001).

This different future time perspective helps explain older adults' general tendencies toward forgiveness (Cheng \& Yim, 2008), as they are more inclined to forgive others than are younger adults, even in the absence of the transgressor making amends (Steiner et al., 2011). In fact, Girard and Mullet (1997) found that 22\% of older adults were unconditional forgivers, no matter the transgression. Perhaps explaining how such a position could be tenable later in life, Steiner and colleagues found that older adults evaluated interpersonal transgressions as less frequent and less intense than did younger adults. They suggested that older adults' enhanced positivity may evoke fewer negative behaviors from their partners, leading to less frequent transgressions. The reduced intensity of transgressions may be due to older adults engaging in less negative reactivity than younger adults after experiencing interpersonal issues (Coats \& Blanchard-Fields, 2008). Together, the reduced frequency and intensity of interpersonal transgressions may help older adults more easily overlook transgressions (Birditt \& Fingerman, 2005), a beneficial strategy later in life.

Older individuals often ignore transgressions they are well aware of others committing in order to preserve and enhance intimacy, which is paramount during this life cycle stage. To older couples looking to preserve marital functioning, it simply may not be worth it to argue about minor issues (Jensen \& Rauer, 2015). They may therefore exhibit different patterns of marital forgiveness than those previously seen in younger couples (Fincham \& Beach, 2002; McNulty, 2008). We know of no study to date, however, that has considered the nature of marital transgressions and forgiveness and its links to marital satisfaction within a dyadic sample of older couples. Such an inquiry is important as forgiveness scholars have called for work that moves beyond examining more general interpersonal transgression scenarios to consider actual transgressions within a specific relationship in older adulthood (Steiner et al., 2012). Given the importance of the marital relationship later in life, the current study therefore sought to explore the nature of marital transgressions in older couples, whether older adults engaged in avoidance of the transgression or the transgressor when dealing with a marital transgression, and the extent to which doing so predicted marital satisfaction.

It is important to acknowledge, however, potential differences in how males and females are socialized to approach interpersonal transgressions. In general, females are encouraged to be more relationship-oriented, often leading them to feel responsible for resolving, or even overlooking, relational issues (Hook et al., 2003). Consequently, women, on average, may be more forgiving than men (Exline et al., 2004). Males, on the other hand, are more likely to withdraw from conflict when compared with women (Fincham \& Beach, 2007), suggesting they may be more likely to avoid their spouse after a transgression. But spouses in long-term, satisfying marriages may be similarly inclined to forgive one another (McCullough et al., 1998). Accordingly, a dyadic consideration is needed to capture any potential gender differences in forgiveness between older husbands and wives.

\section{Methodology}

The inevitability of conflict underscores the importance of forgiveness in marriage (Fincham et al., 2004; Zeidner \& Kloda, 2013). Forgiveness may become especially significant later in life, as minimizing negativity within relationships is critical for older adults' functioning (Bono \& McCullough, 2004; Charles, 2010). However, the ability of older adults to forgive may depend on transgressions experienced, calling for a mixedmethod approach that enables analysis of the transgressions and the resulting forgiveness strategies. Thus, we 
sought to answer the following questions: (1) What kinds of marital transgressions do long-term, higherfunctioning, older married couples experience; (2) how are older adults motivated to deal with specific marital transgressions; (3) how are these motivations linked to husbands and wives' current and future marital satisfaction; and (4) are there gender differences across these patterns?

Among our sample of high-functioning older couples, we hypothesized that the marital transgressions would vary in their nature but, overall, would be minor to moderate. We predicted that some spouses would report no transgression had even occurred in the past year. We made no hypotheses for avoidance, as findings are contradictory between the negative effects found in the forgiveness literature (Fincham et al., 2004) and the positive effects of avoidance in the older adult literature (Birditt \& Fingerman, 2005). However, as reporting no specific transgression may indicate either less severe transgressions or a desire to pursue positivity, we predicted that this approach would be linked to greater concurrent and future marital satisfaction. Finally, we predicted wives would be more likely to report that a transgression had occurred, whereas husbands would be more likely to report greater avoidance of the spouse after a transgression.

\section{Participants}

Sixty-four heterosexual couples were recruited as part of a larger study examining later-life marriages. Recruitment through newspaper advertisements, churches, health-care agencies, and other community organizations took place in the Southeastern United States. To be eligible, couples had to be married, partially retired (i.e., working less than 40 hours a week), and able to drive to the on-campus research center. These inclusion criteria were designed to ensure that couples were in relatively good health and that both spouses had either already fully transitioned into retirement or were in the midst of this transition. Couples, on average, were in their early $70 \mathrm{os}(M H=71, S D H=7.4 ; M W=70, S D W=7.0)$, European American (61 husbands; 60 wives), highly educated (6o husbands and 54 wives attended college), and fully retired (47 couples). Couples reported an average income of $\$ 85,875(S D=\$ 64,074)$ and a total wealth of $\$ 1,082,547$ $(S D=\$ 1,277,611)$. Most couples were in their first marriages (80\%), had been married approximately 42 years $(S D=15)$, and had 2.6 children $(S D=1.3)$.

At Time 2, 55 of the 64 couples (86\%) completed follow-up questionnaires. Reasons for attrition included failure to locate participants, death, health limitations, and declined continued participation. Attrition analyses revealed that couples that participated at both time points did not differ on key constructs from those who only participated during the first assessment.

\section{Procedures}

At Time 1, couples participated in a visit to an on-campus research laboratory that lasted approximately 2-3 hours. Consistent with Auburn University Institutional Review Board (approval number 09-129 EP 0905) procedures, the visit began with couples completing informed consent forms. During the visit, couples took part in several communication tasks. At the end, each spouse was given a questionnaire to finish and mail back to the laboratory within 2 weeks. Couples were compensated $\$ 75$ for participating. At Time 2, approximately 1.5 years later $(M=16.4$ months), couples who agreed to participate were mailed a set of consent forms and questionnaires. Upon returning the packet, couples were paid $\$ 45$.

\section{Measures}

The measures for the study are presented below and were selected to answer the research questions most appropriately.

\section{Forgiveness}

At Time 1, participants completed the Marital Forgiveness Scale-Event (Fincham et al., 2004) to measure 
their experience of forgiveness during the last 12 months. First, spouses were asked to briefly describe a marital transgression by describing a time "when you felt the most wronged or hurt by your partner" in an open-ended response. Spouses were then asked to answer three items about avoidance related to that event on a 6-point Likert scale, with higher scores indicating greater agreement (e.g., "I didn't want to have anything to do with her/him;" $\alpha=.75$ for wives; .78 for husbands). In addition, spouses evaluated how hurt they were by this transgression by responding to the question, "How much hurt or upset did you experience when this event happened?" on a scale of 1 ("very little hurt") to 9 ("most hurt ever felt").

\section{Marital Satisfaction}

Marital satisfaction was measured at both time points using the 24-item Marital Satisfaction Questionnaire for Older Persons (Haynes et al., 1992), which includes areas specific to older adults (e.g., "How satisfied are you with your spouse's physical health?") and general to marriage (e.g., "How satisfied are you with the time you with your spouse spend doing recreational activities?”). Summed responses ranged from 24 to 139 , with higher scores indicating greater satisfaction. Reliability across spouses and waves was strong ( $\alpha \mathrm{s}=.90-.95)$.

\section{Data Analysis Plan}

Data analysis took place in two stages. First, to categorize the marital transgressions, the transgressions were coded using thematic analysis (Braun \& Clarke, 2006). The second author read through all responses and then extracted them into a Microsoft Word document. The transgressions were then described as one sentence statements in memos (e.g., "The spouse criticized the participant's behavior;" "The participant does not recall any transgression happening."), which resulted in 10 different codes. Exemplar quotes were provided to support and enhance the description of each transgression category. From there, the responses were classified into two higher-order coding categories: whether a transgression had occurred (six types) or no transgression had occurred (four types). To ensure trustworthiness of the analysis process and the resultant codes, these memos were reviewed separately by both the second author and an independent scholar to confirm that the codes were appropriate and fit the data.

Next, for spouses who reported a transgression, we fit an Actor-Partner Interdependence Model (APIM; Kashy \& Kenny, 2000) and examined links between both spouses' avoidance after a transgression with concurrent and prospective marital satisfaction in MPLUS 8.o. To note, several spouses who could not recall a specific marital transgression still chose to complete the section on avoidance and were included in the model. Although our sample size is modest, it is consistent with recent recommendations for structural equation modeling (Austin \& Steyerberg, 2015; Iacobucci, 2010). All variables were allowed to co-vary, and missing data was handled using Full Information Maximum Likelihood. We also conducted a series of delta chi-square tests to explore gender differences in the strength of these associations. To evaluate the robustness of the links, we tested a separate model controlling for self-reported transgression severity. Finally, independent samples t-tests were conducted to evaluate whether avoiding the marital transgression altogether was linked to marital satisfaction at either Time 1 or Time 2.

\section{Results}

Table 1 includes descriptive statistics and correlations. Paired samples $t$-tests indicated no gender differences on any of the variables. Wives' marital satisfaction declined from Time 1 to Time $2, t(54)=5.02, p<.001$. Correlations revealed that spouses who reported being more hurt by the transgression were more likely to report engaging in avoidance of the person. 
Table 1. Correlations and Distributional and Scale Properties of Study Variables $(\mathrm{NT} 1=64$ Couples, $\mathrm{NT} 2=$ 55 Couples).

\begin{tabular}{lllll}
\hline Variables & $\mathbf{1 .}$ & $\mathbf{2 .}$ & $\mathbf{3 .}$ & $\mathbf{4}$ \\
\hline 1. Transgression severity & .13 & $.50^{* *}$ & $-.48^{* *}$ & $-.47^{*}$ \\
2. Avoidance of person & $.46^{* *}$ & .10 & -.25 & $-.46^{*}$ \\
3. T1 Satisfaction & -.33 & -.18 & $.57^{* *}$ & $.87^{* *}$ \\
4. T2 Satisfaction & $-.49^{*}$ & $-.59^{* *}$ & $.61^{* *}$ & $.59^{* *}$ \\
M (SD) H & $4.53(2.41)$ & $2.59(1.13)$ & $116.36(18.07)$ & $113.85(17.57)$ \\
M (SD) W & $5.14(2.33)$ & $2.57(1.30)$ & $117.55(14.57)$ & $113.52(15.28)$ \\
\hline
\end{tabular}

Note. Correlations noted below the diagonal are for husbands and those noted above the diagonal are for wives. Correlations across spouses are underscored and in the diagonal. ${ }^{* *} p \leq .01 ;{ }^{*} p \leq .05$.

\section{What Marital Transgressions Do Older Couples Experience?}

As seen in Table 2, thematic analysis of the marital transgressions revealed two higher-order categories: one in which spouses reported a transgression had occurred ( $n=51 ; n=26$ wives; $n=25$ husbands) and one in which no transgression was reported ( $n=77 ; n=38$ wives, $n=39$ husbands). Looking first at the marital transgressions, we found five types. The first, and most common, type of marital transgression was that participants reported that their spouse behaved badly towards them. Examples of this transgression included speaking angrily towards them, not being fully honest, and issues of trust. The second most frequently occurring type of marital transgression was that the spouse criticized behavior or abilities of the participant. Examples of this transgression included belittling the individual, criticizing their memory, or speaking poorly of them to others. The third most common type of marital transgression was financial issues. Examples of this type of transgression included different desires regarding spending, concerns about the amount of financial assistance provided to children, and misplacing money. The fourth most common type of marital transgression was that the spouse did not appreciate or listen. Examples of this type of transgression included not noticing an individual's efforts, interrupting the individual, and not being interested in hearing what the individual had to say. The sixth most common type of marital transgression was the spouse changed things or routines. Examples of this type of transgression included the spouse not being consulted on changes, constant changes in routines, or rearranging things in the house. The least common type of marital transgression was health issues. Examples of this type of transgression included not being sensitive to health limitations, not responding as desired during a health challenge, and being frustrated with the spouse's health limitations. Across the marital transgressions, husbands and wives were, overall, equally likely to be represented within each category. 
Table 2. Examples, Acts, and Domains of Marital Transgressions.

\begin{tabular}{|c|c|c|}
\hline Examples of Marital Transgressions & $\begin{array}{l}\text { Types of Marital } \\
\text { Transgressions }\end{array}$ & Domains \\
\hline $\begin{array}{l}\text { "He was frustrated with himself and spoke angrily with me." } \\
\text { (Wife) } \\
\text { "I was going out the door one night at home to mail a letter } \\
\text { downstairs. She wanted me to stay and watch a TV program } \\
\text { with her. She slammed door." (Husband) }\end{array}$ & $\begin{array}{c}\text { Spouse behaved badly } \\
\text { ( } n=16 ; n=9 \text { wives, } n=7 \\
\text { husbands) }\end{array}$ & \multirow{6}{*}{$\begin{array}{l}\text { Transgression } \\
\text { Reported } \\
(n=51 ; n=26 \\
\text { wives, } n=25 \\
\text { husbands) }\end{array}$} \\
\hline $\begin{array}{l}\text { "When he thinks his way is the only way to cook something." } \\
\text { (Wife) } \\
\text { "When she criticizes and fusses at me. She wants to change my } \\
\text { life to her wishes, instead of letting me be myself." (Husband) }\end{array}$ & $\begin{array}{l}\text { Spouse criticized behavior } \\
\text { or abilities } \\
\text { ( } n=8 ; n=3 \text { wives, } n=5 \\
\text { husbands) }\end{array}$ & \\
\hline $\begin{array}{l}\text { "Perhaps I feel wronged when we don't see eye to eye on the } \\
\text { amount things cost." (Wife) } \\
\text { "My wife wanted to give and do more than I for our children in } \\
\text { lieu of conservative gifting. I fear financially more for our } \\
\text { future." (Husband) }\end{array}$ & $\begin{array}{c}\text { Financial issue } \\
(n=8 ; n=3 \text { wives, } n=5 \\
\text { husbands) }\end{array}$ & \\
\hline $\begin{array}{l}\text { "I worked hard to clean up, did a lot of the driving to get here, } \\
\text { and felt hurt when my husband wanted to complain about the } \\
\text { mold rather than realizing I was hurting and exhausted." } \\
\text { (Wife) } \\
\text { "I was not listened to when I had something important for me } \\
\text { to say." (Husband) }\end{array}$ & $\begin{array}{l}\text { Spouse did not appreciate } \\
\text { or listen } \\
\text { ( } n=7 ; n=4 \text { wives, } n=3 \\
\text { husbands) }\end{array}$ & \\
\hline $\begin{array}{l}\text { "We were taking a trip and he invited someone to stay in our } \\
\text { room." (Wife) } \\
\text { "Has to do with constantly changing the routine of how we } \\
\text { care for my mother." (Husband) }\end{array}$ & $\begin{array}{l}\text { Spouse changed things or } \\
\text { routines } \\
\text { ( } n=6 ; n=4 \text { wives, } n=2 \\
\text { husbands) }\end{array}$ & \\
\hline $\begin{array}{l}\text { "I was told to wear a collar (neck brace). I did not want to. I } \\
\text { could not breathe with it, I screamed at (husband) to get out of } \\
\text { the room because he would not remove it for me." (Wife) } \\
\text { "I am hard of hearing and there are times when I ask, "What are } \\
\text { you saying?" She will not respond." (Husband) }\end{array}$ & $\begin{array}{l}\text { Health issue } \\
(n=5 ; n=2 \text { wives, } n=3 \\
\text { husbands) }\end{array}$ & \\
\hline "N/A" & $\begin{array}{c}\text { N/A or left blank } \\
(n=30 ; n=19 \text { wives, } n= \\
11 \text { husbands) }\end{array}$ & \multirow{4}{*}{$\begin{array}{l}\text { No } \\
\text { Transgression } \\
\text { Reported } \\
\text { ( } n=77 ; n= \\
38 \text { wives, } \\
n=39 \\
\text { husbands) }\end{array}$} \\
\hline $\begin{array}{l}\text { "There has been no time I was wronged or hurt." (Wife) } \\
\text { "It just doesn't happen." (Husband) }\end{array}$ & $\begin{array}{c}\text { No transgression } \\
\text { occurred } \\
(n=24 ; n=8 \text { wives, } n= \\
16 \text { husbands })\end{array}$ & \\
\hline $\begin{array}{l}\text { "There must be something, we aren't perfect! But I don’t } \\
\text { remember feeling hurt or wronged by my husband." (Wife) } \\
\text { "I honestly cannot think of such an incident." (Husband) }\end{array}$ & $\begin{array}{l}\text { No memory of an event } \\
(n=20 ; n=9 \text { wives, } n= \\
11 \text { husbands })\end{array}$ & \\
\hline $\begin{array}{l}\text { "I don't keep score or hold grudges." (Wife) } \\
\text { "I've been angry at my spouse several times in the past } 12 \\
\text { months, but that doesn't rise to the level of 'wronged' or 'hurt.' } \\
\text { I'm not a great believer in keeping score." (Husband) }\end{array}$ & $\begin{array}{l}\text { Choose to not remember } \\
\text { any transgression } \\
\text { ( } n=3 ; n=2 \text { wives, } n=1 \\
\text { husbands) }\end{array}$ & \\
\hline
\end{tabular}

To note, none of the marital transgressions reported were severe in nature (e.g., infidelity, violence), and most would be considered minor (e.g., "She rearranged some closets and forgot where she put things.") to moderate ("He must have spoken derogatorily about me to a daughter, which I picked up on by her change in attitude 
toward me."). Consistent with this interpretation, spouses evaluated these marital transgressions as moderately hurtful or upsetting on average (4.53 for husbands and 5.14 for wives on a 9-point Likert scale).

The majority of spouses, however, reported no marital transgression (see Table 2). How this was done differed though across the spouses, although husbands and wives were overall equally likely to report no marital transgression. Most commonly, participants chose to leave the space blank or to write in "N/A" or "N/R." More wives utilized this option $(n=19)$ than did husbands $(n=11)$. But many spouses felt compelled to expand upon this answer with more specific details. The largest number who did so reported that no transgression occurred. Within this category, spouses would state that such a thing had not happened in the past 12 months or even ever at all. This category characterized twice the number of husbands $(n=16)$ than wives $(n=8)$. The second largest category of spouses who responded stated that they had no memory of an event. Spouses stated that they did not recall anything happening or that, if it had, it must have been so minor as to not merit remembering it. Finally, a small number of spouses reported that they chose to not remember any transgression. This category was differentiated from the prior one, in that spouses reported a deliberate action to not recall any transgressionsmostly as they reported that dwelling on past incidents was either not consistent with their personality or not beneficial. There were no marked gender differences across the latter two categories.

As a follow-up analysis, a chi-square test was conducted to examine whether spouses were similar in their likelihood of reporting a marital transgression. The analysis revealed that there was more consensus between spouses than expected, $\chi^{2}(1)=4.02, p=.045$, with 27 couples $(42 \%)$ in which both spouses reported no transgression occurred and 14 couples (22\%) in which both spouses reported a transgression had occurred. Only the husband reported a transgression in 11 couples (17\%), and only the wife reported one occurred in 12 couples (19\%).

\section{Does Avoidance of Either the Person or the Transgression Predict Marital Satisfaction?}

To examine how husbands' and wives' avoidance of the spouse after a transgression contributed to their own and each other's marital satisfaction at two time points, we fit an APIM (Kashy \& Kenny, 2000). In line with previous recommendations for analyzing distinguishable dyads (Peugh et al., 2013), the model was fully saturated $\left(\chi_{2}=0.00, d f=0\right)$, and thus absolute model fit indices are not available. There were no significant differences in the pathways when we compared the uncontrolled and controlled model, and thus we present the uncontrolled models per recommendations (Simmons et al., 2011).

As seen in Figure 1, husbands' avoidance was negatively associated with their own marital satisfaction, but not their wives', at Time 1. Husbands' use of avoidance, however, predicted less marital satisfaction for both spouses at Time 2. This model explained $64.5 \%$ of the variance in husbands' marital satisfaction at Time 2 and $87.5 \%$ of the variance in wives' marital satisfaction at Time 2. Delta chi-square tests revealed gender differences in both the actor and partner effects. Specifically, husbands' avoidance was linked more strongly to their own marital satisfaction than wives' avoidance was linked to their own marital satisfaction, $\Delta \chi 2(1)=$ $12.22, p=.0005$. Also, husbands' avoidances were linked more strongly to their wives' satisfaction than wives' avoidance was linked to husbands' marital satisfaction, $\chi 2(1)=6.75, \mathrm{p}=.009$. 
Figure 1. Actor-Partner Interdependence Model linking both spouses' avoidance after a transgression with concurrent and prospective marital satisfaction (NT1 $=64$ Couples, $N T 2=55$ Couples).

Time 1

Time 2

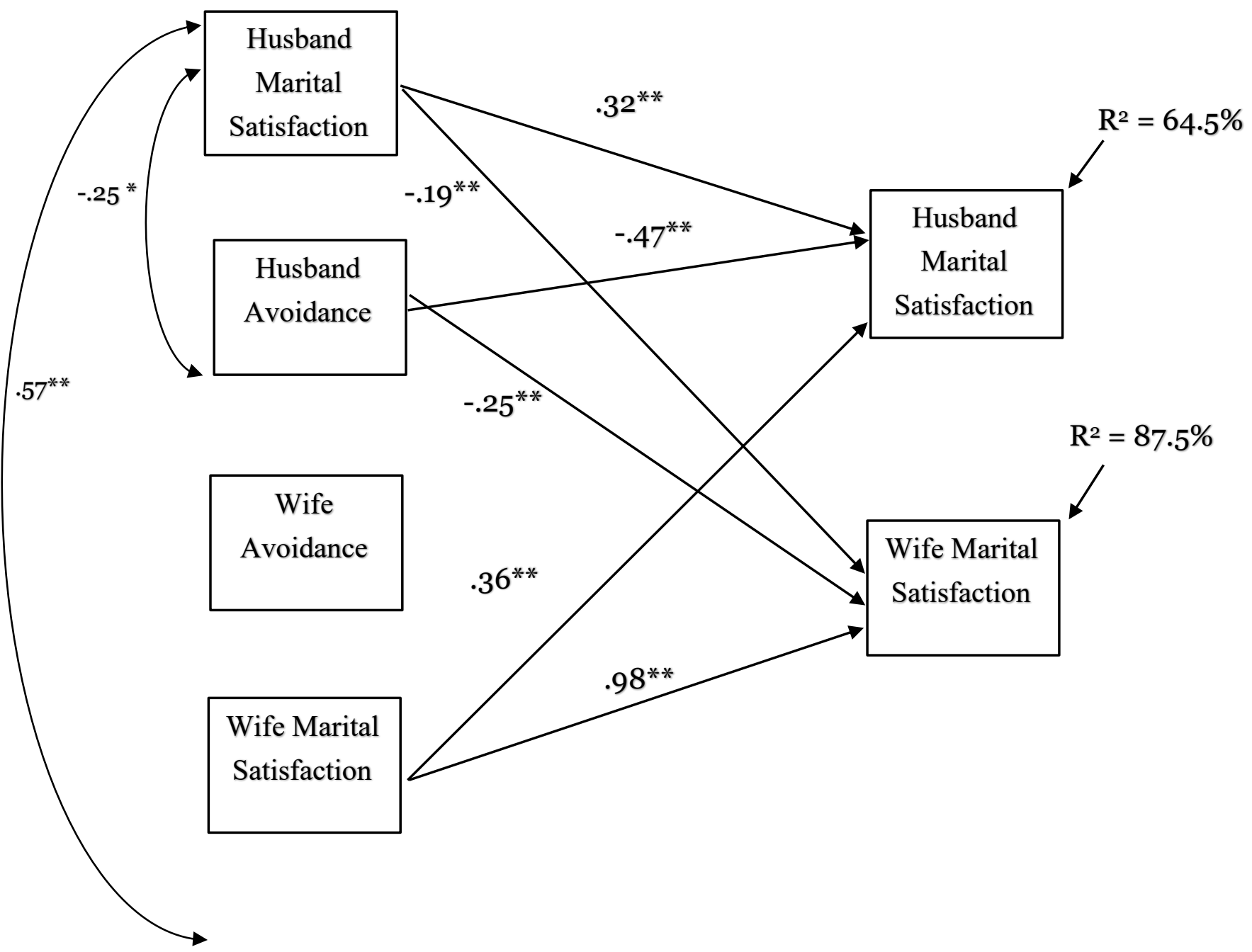

Note: Only significant pathways are shown with standardized path coefficients. The model was fully saturated: $\chi 2=0.00$, $d f=0$ and thus absolute fit indices are not available. ${ }^{* *} p \leq .01 ;{ }^{*} p \leq .05$.

Finally, a series of independent samples $t$-tests were conducted to compare marital satisfaction based on whether spouses reported a transgression had occurred or not (see Table 2 for these categories). When husbands reported that no specific transgression had taken place in the past year, they were more maritally satisfied at both Time $1, t(62)=3.03, p=.004$, and Time $2, t(53)=2.83, p=.007$. Wives who reported that no transgression occurred were more satisfied, but only at Time $2, t(53)=2.23, p=.030$. For cross-spouse linkages, wives of husbands who reported no transgression were more satisfied at both Time $1, t(62)=2.44, p$ $=.018$, and at Time $2, t(53)=2.24, p=.029$. In contrast, husbands' marital satisfaction at either Time 1 or Time 2 did not differ based on whether wives reported a transgression had occurred or not. 


\section{Discussion}

The ability to navigate transgressions in close relationships is imperative for both their quality and longevity. Despite the importance of forgiveness in marriage (Fincham \& Beach, 2001; 2007), there is scant literature examining this process in older couples. Our findings indicated that such a focus is warranted, as there may be distinctive ways to enact the forgiveness process that have different associations with marital satisfaction at this critical stage of the life course. Perhaps the most notable finding was that many of the older spouses here did not report a marital transgression, and that not doing so was linked to greater marital satisfaction. Thematic analyses revealed that the marital transgressions that did occur varied but were relatively minor to moderate in nature. If, however, husbands reported avoiding their spouse after such a marital transgression occurred, both spouses were less satisfied a year later. If different transgressions and forgiveness approaches could be identified within this modestly sized, homogenous sample, then more attention should be devoted to understanding marital transgressions in later life and what forgiveness approaches spouses use in response. Doing so may reveal several, and we argue, meaningful, nuances in the forgiveness process among older, stably married couples.

\section{What Marital Transgressions-if Any-Do Older Couples Experience?}

Despite the normality of partners occasionally hurting one another (Fincham et al., 2004), our work is consistent with larger, cross-cultural work showing that older adults experience transgressions less frequently than do younger adults (Steiner et al., 2011). Further, forgiveness motivations often seen as harmful in younger adults may be either neutral or even beneficial later in life. For example, practitioners tend to discourage avoidance of issues in newer marriages as it can contribute to negative communication patterns (Gottman \& Krokoff, 1989). But, as Gordon et al. (2000) state, not all negative events in marriage require forgiveness. Hence, our conceptualization of transgressions may need to reflect this consideration, especially among older adults seeking to maximize relational positivity (Penningroth \& Scott, 2012).

Thematic analyses among this higher-functioning sample revealed that spouses who reported a transgression described relatively minor events, with no spouses describing severe transgressions. Although there were not gender differences in these transgressions, some evidence suggests differences based on developmental stage. Though most of the transgression categories mapped on to previous work with younger couples (Sanford, 2003; Williamson et al., 2013), the smallest category, health issues, appears unique to older couples. Examples reflected transgressions related to both how the spouse handled their own health issues and how they were treated in response to health challenges. These findings are consistent with work suggesting that how spouses handle health issues in later life becomes a marital concern, rather than just an individual one (Cano et al., 2005; Rauer \& Jensen, 2016). Moreover, although financial issues emerge in work with younger couples, the transgressions here appeared more focused on financial support of adult children, an issue unique to this life stage. Although some research suggests that motives for and comfort with inter vivos transfers differ between families (Kohli \& Kunemund, 2003), understanding how these differ across older couples may be important. Notably, when spouses would describe these or any of the transgressions, they would often soften their statements with caveats such as "My husband does not hurt my feelings very often" or "We have discussed this, and she hardly does it anymore." Such statements underscore that spouses in this sample may have reported marital transgressions but often did not think of them as necessarily requiring forgiveness.

\section{Is it Better to Forget? It Depends on How One Does It}

Whether due to less severe marital issues or a higher threshold for irritation, older couples experience events warranting forgiveness less frequently than do younger couples (Steiner et al., 2011). Indeed, one participant stated, "I never feel that my wife intentionally hurts or wrongs me. Therefore, any feeling of hurt or being wronged is fleeting, temporary, and virtually unimportant." Older adults' desire to intentionally augment emotional intimacy in close relationships is consistent with SST (Luong et al., 2011). Further highlighting the 
intentionality of these efforts, one spouse observed, “I don't know whether I can't remember, or I choose not to remember." Such observations suggest we may need to reconsider the use of avoidance and its effects, as Fincham and colleagues (2004) conceptualized avoidance as a uniformly negative dimension of forgiveness. To the extent that we captured avoidance of the transgression altogether for some of the spouses (an interpretation supported by their written explanations), it did not appear problematic here, as spouses were more satisfied when they reported no transgressions. Findings may reflect that these couples are accurately reporting that no transgressions had occurred in their marriage in the past year, which could explain their higher marital functioning, as could the relatively lower-risk nature of our sample. However, the inevitability of conflict may make this less likely even in stably married couples (Duba et al., 2011; Fincham et al., 2006; Zeidner \& Kloda, 2013). By choosing to pick their battles (Birditt \& Fingerman, 2005), spouses, it appears, attempt to protect the quality of their relationship, and our results suggest their efforts are not in vain.

In contrast, avoiding the person appeared to be uniformly problematic among older couples. In line with previous work (Fincham et al., 2004), when husbands avoided their spouse after a transgression, both spouses reported being less satisfied 16 months later. Regarding why husbands' avoidance was more salient than was wives' in our sample, it may be that men withdraw more completely than do women after a problem (Curran et al., 2011), making it more difficult to maintain the lines of communication in the marriage. Avoiding one's spouse, arguably the most important tie that adults can have (Finkel et al., 2014), may be particularly problematic later in life, when older adults are theorized to be trying to increase the closeness of their inner circle in light of their mortality (Carstensen, 1992). Given that men tend to have smaller social networks than do women (Antonucci et al., 2013), their reliance on their spouse for their social needs is amplified (Antonucci \& Akiyama, 1987). Avoiding their wives even to a small degree, as we found here, would be appreciable, as these husbands' social needs could then go unmet for the duration of that avoidance. For wives, husbands' avoidance may have been especially difficult given that they are often socialized to share problems and build relationships, whereas husbands are taught to be more independent and discouraged from sharing challenges (Brown, 2012).

Together, these findings offer preliminary support for the importance of disentangling avoidance of the problem from avoidance of a person as they may elicit very different reactions from spouses later in life. Such a distinction is likely absent from current assessments of forgiveness, as they were likely normed with younger couples who tend to withdraw from a spouse when problems arise (Caughlin, 2002; Marchand \& Hock, 2000). Given that avoidance of the problem appears to be more of a uniquely later-life approach, researchers may want to address potential measurement limitations by expanding current assessments to not only tap into this difference between avoiding the problem versus the person, but also to capture spouses' motivations for these behaviors. The extent to which a relationship-enhancing motivation underlies spouses' avoidance likely shapes its eventual effects.

\section{Translational Section}

Although study results certainly offer more nuanced considerations for researchers examining forgiveness patterns among older couples, our findings also have practical relevance for clinicians working with older couples, as well as these romantic partners themselves. First, therapists working with older couples may need to be aware that: Often, as couples age, they actively strive to minimize conflict. This is done in an attempt to maximize positivity as couples age. At times, this may result in older couples avoiding discussions of offenses committed-and that may not always be a bad thing. It seems that actively working through and processing conflictual interactions may be more important for younger couples than older ones. Therapists should be aware of this and resist the temptation to provide similar communication training to a couple in their 70 as they would to a couple in their 20 . 
For the partners, themselves, as they age, they may benefit from "letting certain issues go" without drawn-out processing or validating, resulting in forgiveness. However, it is important for partners to remember that although avoiding a problematic issue may not be damaging, avoiding one's partner likely is, especially for men. When husbands engage in greater avoidance after a transgression, both spouses tend to be less happy. Older couples are encouraged to more proactively recognize the positive aspects of their relationships and be slower to dive into the grinding daily stressors that add potential for conflict.

\section{Considerations and Conclusion}

Although our study included several notable strengths (longitudinal, multi-method data with older couples), there were limitations. First, generalizability was limited (e.g., financially stable, White, heterosexual sample). Expanding the scope is crucial, as race, sexual orientation, education, and income can all influence marital functioning (Broman, 1993; Julien et al., 1999; Karney \& Bradbury, 1995). As financial challenges contribute to marital conflict (Conger et al., 1994), including socioeconomically diverse couples may have revealed both more frequent instances of spouses feeling offended and spouses navigating the forgiveness process differently under financial strain. The modest sample size of those reporting transgressions may also have been influenced by the highly satisfied, committed nature of this sample. This factor may have made the transgressions less severe and thus easier to avoid (Finkel et al., 2002). Second, observational data of the forgiveness process could determine whether spouses were choosing to ignore transgressions or if spouses were accurately reporting that no transgressions had occurred. Lastly, as each spouse was asked to report a time he or she felt the "most hurt" in the past year, it may be that not all older spouses were able to quickly recall transgressions during that time frame. Older adults tend to more easily recall distant transgressions rather than recent ones (Ghaemmaghami et al., 2011), suggesting a broader time frame may be useful. Further, simply examining the instance in which a spouse reported feeling "most hurt" may not capture the most common way couples handle marital transgressions (Fincham et al., 2020). The forgiveness process may differ for couples' run-of-the-mill offenses or if we had investigated multiple instances of forgiveness.

In conclusion, our study highlights the benefits of taking a developmental, dyadic perspective when examining forgiveness, as not only do the motivations reported by older couples differ, but the associations between these dimensions and husbands' and wives' marital satisfaction appear to be rather unique, as well. Despite coping with cognitive decline, physical limitations, and shrinking social circles, older adults are quite adept at maintaining interpersonal positivity (Jensen \& Rauer, 2015). Foregoing the grind of processing daily conflict and focusing rather on relationship-enhancing topics seems quite effective for aging couples (Birditt \& Fingerman, 2003), and researchers and practitioners should examine whether such an approach could be useful for maintaining the quality of marriages earlier in a couple's relationship, as well. Although such relationship-promoting actions may occur more naturally later in life (Birditt \& Fingerman, 2005; Charles, 2010), there is evidence that such skills-especially forgiveness-can be taught (Fincham, 2017). For example, a recent intervention, focused on enhancing couples' perspective-taking abilities, appeared to help couples step away from the issues in the name of preserving relationship quality (Finkel et al., 2013). Adopting a neutral, third-party perspective during conflict may aid couples in deciding whether or not a transgression is even worth pursuing. Deciding to overlook minor transgressions may require more work earlier in the lifespan, but the benefits of doing so appear to warrant such efforts. 


\section{References}

Antonucci, T. C., \& Akiyama, H. (1987). An examination of sex differences in social support among older men and women. Sex Roles, 17, 737-749. https://doi.org/10.1007/bfoo287685

Antonucci, T. C., Ajrouch, K. J., \& Birditt, K. S. (2013). The convoy model: Explaining social relations from a multidisciplinary perspective. The Gerontologist, 54(1), 82-92.

https://doi.org/10.1093/geront/gnt118

Birditt, K. S., \& Fingerman, K. L. (2003). Age and gender differences in adults' descriptions of emotional reactions to interpersonal tensions. The Journals of Gerontology, Series B, 58(4), 237-245. https://doi.org/10.1093/geronb/58.4.p237

Birditt K. S., \& Fingerman K. L. (2005). Do we get better picking our battles? Age group differences in descriptions of behavioral reactions to interpersonal tension. Journal of Gerontology, Series B, 6o(3), 121-128. https://doi.org/10.1093/geronb/60.3.p121

Bono, G., \& McCullough, M. E. (2004). Religion, forgiveness, and adjustment in older adults. In K. W. Schaie, N. Krause, \& A. Booth (Eds.), Religious influences on health and well-being in the elderly (pp. 163186). Springer.

Braithwaite, S. R., Selby, E. A., \& Fincham, F. D. (2011). Forgiveness and relationship satisfaction: Mediating mechanisms. Journal of Family Psychology, 25(4), 551-559. https://doi.org/10.1037/aoo24526

Braun, V., \& Clarke, V. (2006). Using thematic analysis in psychology. Qualitative Research in Psychology, 3(2), 77-101. https://doi.org/10.1191/1478088706qpo63oa

Broman, C. L. (1993). Race differences in marital well-being. Journal of Marriage and Family, 55(3), 724732. https://doi.org/10.2307/353352

Brown, B. (2012). Daring greatly. Penguin Group.

Cano, A., Johansen, A. B., Leonard, M. T., \& Hanawalt, J. D. (2005). What are the marital problems of patients with chronic pain? Current Pain and Headache Reports, 9(2), 96-100. https://doi.org/10.1007/s11916-005-0045-0

Carstensen, L. L. (1992). Social and emotional patterns in adulthood: Support for socioemotional selectivity theory. Psychology and Aging, 7(3), 331-338. https://doi.org/10.1037//o882-7974.7.3.331

Caughlin, J. P. (2002). The demand/withdraw pattern of communication as a predictor of marital satisfaction over time: Unresolved issues and future directions. Human Communication Research, 28(1), 49-85. https://doi.org/10.1093/hcr/28.1.49

Charles, S. T. (2010). Strength and vulnerability integration: A model of emotional well-being across adulthood. Psychological Bulletin, 136(6), 1068-1091. https://doi.org/10.1037/ao021232

Charles, S. T., \& Carstensen, L. L. (2007). Emotion regulation and aging. In J. J. Gross (Ed.), Handbook of emotion regulation (pp. 207-327). Guilford Press.

Cheng, S.-T., \& Yim, Y.-K. (2008). Age differences in forgiveness: The role of future time perspective. Psychology and Aging, 23(3), 676-680. https://doi.org/10.1037/0882-7974.23.3.676

Coats, A. H., \& Blanchard-Fields, F. (2008). Emotion regulation in interpersonal problems: The role of cognitive-emotional complexity, emotion regulation goals, and expressivity. Psychology and Aging, 23(1), 39-51. https://doi.org/10.1037/0882-7974.23.1.39

Conger, R. D., Ge, X., Elder, G. H., Jr., Lorenz, F. O., \& Simons, R. L. (1994). Economic stress, coercive family process, and developmental problems of adolescents. Child Development, 65(2), 541-561.

https://doi.org/10.2307/1131401 
Curran, M., Ogolsky, B., Hazen, N., \& Bosch, L. (2011). Understanding marital conflict 7 years later from prenatal representations of marriage. Family Process, 5o(2), 221-234. https://doi.org/10.1111/j.15455300.2011.01356.x

Duba, J. D., Hughey, A. W., Lara, T., \& Burke, M. G. (2012). Areas of marital dissatisfaction among long-term couples. Adultspan Journal, 11(1), 39-54. https://doi.org/10.1002/j.2161-0029.2012.00004.x

Exline, J. J., Baumeister, R. F., Bushman, B. J., Campbell, W. K., \& Finkel, E. J. (2004). Too proud to let go: Narcissistic entitlement as a barrier to forgiveness. Journal of Personality and Social Psychology, 87(6), 894-912. https://doi.org/10.1037/0022-3514.87.6.894

Fincham, F. D. (2017). Translational family science and forgiveness: A healthy symbiotic relationship? Family Relations, 66(4), 584-600. https://doi.org/10.1111/fare.12277

Fincham, F. D., \& Beach, S. R. H. (2001). Forgiving in close relationships. In F. Columbus (Ed.), Advances in Psychology Research (Vol. 7, 163-197). Nova Science Publishers.

Fincham, F. D., \& Beach, S. R. H. (2002). Forgiveness in marriage: Implications for psychological aggression and constructive communication. Personal Relationships, 9(3), 239-251. https://doi.org/10.1111/1475-6811.00016

Fincham, F. D., \& Beach S. R. H. (2007). Forgiveness and marital quality: Precursor or consequence in wellestablished relationships. Journal of Positive Psychology, 2(4), 260-268. https://doi.org/10.1080/17439760701552360

Fincham, F. D., Beach, S. R. H., \& Davila, J. (2004). Forgiveness and conflict resolution in marriage. Journal of Family Psychology, 18(1), 72-81. https://doi.org/10.1037/0893-3200.18.1.72

Fincham, F. D., Hall, J. H., \& Beach, S. R. H. (2006). Forgiveness in marriage: Current status and future directions. Family Relations, 55(4), 415-427. https://doi.org/10.1111/j.1741-3729.2005.callf.x-i1

Fincham, F. D., May, R., \& Beach, S. R. H. (2020). Forgiveness interventions for optimal close relationships: Problems and prospects. In C. Knee \& H.T. Reis (Eds.), Positive approaches to optimal relationship development (pp. 304-325). Cambridge University Press. https://doi.org/10.1017/cbo9781316212653.015

Finkel, E. J., Hui, C. M., Carswell, K. L., \& Larson, G. M. (2014). The suffocation of marriage: Climbing Mount Maslow without enough oxygen. Psychological Inquiry, 25(1), 1-41. https://doi.org/10.1080/1047840x.2014.863723

Finkel, E. J., Rusbult, C. E., Kumashiro, M., \& Hannon, P. A. (2002). Dealing with betrayal in close relationships: Does commitment promote forgiveness? Journal of Personality and Social Psychology, 82(6), 956-974. https://doi.org/10.1037//o022-3514.82.6.956

Finkel, E. J., Slotter, E. B., Luchies, L. B., Walton, G. M., \& Gross, J. J. (2013). A brief intervention to promote conflict reappraisal preserves marital quality over time. Psychological Science, 24(8), 1595-1601. https://doi.org/10.1177/0956797612474938

Ghaemmaghami, P., Allemand, M., \& Martin, M. (2011). Forgiveness in younger, middle-aged and older adults: Age and gender matters. Journal of Adult Development, 18(4), 192-203. https://doi.org/10.1007/s10804-011-9127-x

Girard, M., \& Mullet, E. (1997). Forgiveness in adolescents, young, middle-aged, and older adults. Journal of Adult Development, 4(4), 209-220. https://doi.org/10.1007/bfo2511412

Gottman, J. M., \& Krokoff, L. J. (1989). Marital interaction and satisfaction: A longitudinal view. Journal of Consulting and Clinical Psychology, 57(1), 47-52. https://doi.org/10.1037/0022-006x.57.1.47 
Gordon, K. C., \& Baucom, D. H. (1998). Understanding betrayals in marriage: A synthesized model of forgiveness. Family Process, 37(4), 425-449. https://doi.org/10.1111/j.1545-5300.1998.00425.x

Gordon, K. C., Baucom, D. H., \& Snyder (2000). The use of forgiveness in marital therapy. In M. E. McCullough, K. L. Pargament, \& C. E. Thoresen (Eds.), Forgiveness: Theory, research, and practice (pp. 203-227). The Guilford Press.

Haynes, S. N., Floyd, F. J., Lemsky, C., Rogers, E., Winemiller, D., Heilman, N., Werle, M., Murphy, T., \& Cardone, L. (1992). The Marital Satisfaction Questionnaire for Older Persons. Psychological Assessment, 4(4), 473-482. https://doi.org/10.1037/1040-3590.4.4.473

Hook, M. K., Gerstein, L. H., Detterich, L., \& Gridley, B. (2003). How close are we? Measuring intimacy and examining gender differences. Journal of Counseling and Development, 81(4), 462-472. https://doi.org/10.1002/j.1556-6678.2003.tboo273.x

Jensen, J. F., \& Rauer, A. J. (2015). Marriage work in older couples: Disclosure of marital problems to spouses and friends over time. Journal of Family Psychology, 29(5), 732-743. https://doi.org/10.1037/famooooo99

Julien, D., Chartrand, E., \& Bégin, J. (1999). Social networks, structural interdependence, and conjugal adjustment in heterosexual, gay, and lesbian couples. Journal of Marriage and Family, 61(2), 516530. https://doi.org/10.2307/353766

Karney, B. R., \& Bradbury, T. N. (1995). The longitudinal course of marital quality and stability: A review of theory, method, and research. Psychological Bulletin, 118(1), 3-34. https://doi.org/10.1037/o0332909.118.1.3

Kohli, M., \& Künemund, H. (2003). Intergenerational transfers in the family: What motivates giving? In V. L. Bengtson \& A. Lowenstein (Eds.), Global aging and challenges to families (pp. 123-142). Aldine de Gruyter.

Luong, G., Charles, S. T., \& Fingerman, K. L. (2011). Better with age: Social relationships across adulthood. Journal of Social and Personal Relationships, 28(1), 9-23. https://doi.org/10.1177/0265407510391362

Marchand, J. F., \& Hock, E. (2000). Avoidance and attacking conflict-resolution strategies among married couples: Relations to depressive symptoms and marital satisfaction. Family Relations, 49(2), 201206. https://doi.org/10.1111/j.1741-3729.2000.00201.x

McCullough, M. E., Rachal, K. C., Sandage, S. J., Worthington Jr, E. L., Brown, S. W., \& Hight, T. L. (1998). Interpersonal forgiving in close relationships: II. Theoretical elaboration and measurement. Journal of Personality and Social Psychology, 75(6), 1586-1603. https://doi.org/10.1037/oo223514.75.6.1586

McNulty, J. K. (2008). Forgiveness in marriage: Putting the benefits into context. Journal of Family Psychology, 22(1), 171-175. https://doi.org/10.1037/0893-3200.22.1.171

Molden, D. C., \& Finkel, E. J. (2010) Motivations for promotion and prevention and the role of trust and commitment in interpersonal forgiveness. Journal of Experimental Social Psychology, 46(2), 255268. https://doi.org/10.1016/j.jesp.2009.10.014

Paleari, F. G., Regalia, C., \& Fincham, F. (2005). Marital quality, forgiveness, empathy, and rumination: A longitudinal analysis. Personality and Social Psychology Bulletin, 31(3), 368-378. https://doi.org/10.1177/0146167204271597

Penningroth, S. L., \& Scott, W. D. (2012). Age-related differences in goals: Testing predictions from selection, optimization, and compensation theory and socioemotional selectivity theory. The International Journal of Aging and Human Development, 74(2), 87-111. https://doi.org/10.2190/ag.74.2.a 
Peugh, J. L., DiLillo, D., \& Panuzio, J. (2013). Analyzing mixed-dyadic data using structural equation models. Structural Equation Modeling: A Multidisciplinary Journal, 20(2), 314-337. https://doi.org/10.1080/10705511.2013.769395

Rauer, A., \& Jensen, J. F. (2016). These happy golden years? The role of retirement in marital quality. In J. Bookwala (Ed.), Couple relationships in middle and later years: Their nature, complexity, and role in health and illness (pp. 157-176). American Psychological Association.

Sanford, K. (2003). Problem-solving conversations in marriage: Does it matter what topics couples discuss? Personal Relationships, 10(1), 97-112. https://doi.org/10.1111/1475-6811.00038

Simmons, J. P., Nelson, L. D., \& Simonsohn, U. (2011). False-positive psychology: Undisclosed flexibility in data collection and analysis allows presenting anything as significant. Psychological Science, 22(11), 1359-1366. https://doi.org/10.1177/0956797611417632

Steiner, M., Allemand, M., \& McCullough, M. E. (2011). Age differences in forgivingness: The role of transgression frequency and intensity. Journal of Research in Personality, 45(6), 670-678. https://doi.org/10.1016/j.jrp.2011.09.004

Steiner, M., Allemand, M., \& McCullough, M. E. (2012). Do agreeableness and neuroticism explain age differences in the tendency to forgive others? Personality and Social Psychology Bulletin, 38(4), 441453. https://doi.org/10.1177/0146167211427923

Story, T. N., Berg, C. A., Smith, T. W., Beveridge, R., Henry, N. J. M., \& Pearce, G. (2007). Age, marital satisfaction, and optimism as predictors of positive sentiment override in middle-aged and older married couples. Psychology and Aging, 22(4), 719-727. https://doi.org/10.1037/08827974.22.4.719

Williamson, H. C., Hanna, M. A., Lavner, J. A., Bradbury, T. N., \& Karney, B. R. (2013). Discussion topic and observed behavior in couples' problem-solving conversations: Do problem severity and topic choice matter? Journal of Family Psychology, 27(2), 330-335. https://doi.org/10.1037/a0031534

Wilson, B. J., \& Gottman, J. M. (2002). Marital conflict, repair, and parenting. In M. H. Bornstein (Ed.), Handbook of parenting: Volume 4: Social conditions and applied parenting (2nd ed., 227-258). Lawrence Erlbaum Associates.

Zeidner, M., \& Kloda, I. (2013). Emotional intelligence (EI), conflict resolution patterns, and relationship satisfaction: Actor and partner effects revisited. Personality and Individual Differences, 54(2), 278283. https://doi.org/10.1016/j.paid.2012.09.013

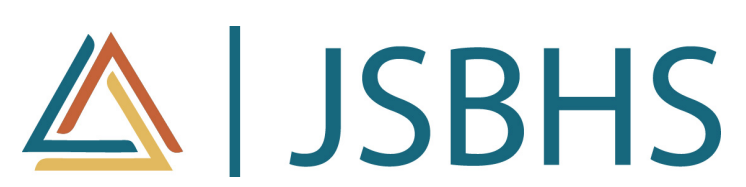

The Journal of Social, Behavioral, and Health Sciences (JSBHS), cosponsored by the College of Health Professionals and the College of Social and Behavioral Sciences at Walden University, is a peer-reviewed, online, interdisciplinary journal focusing on theoretically based research that addresses contemporary national and international issues. $J S B H S$ articles include peer-reviewed research reports, brief reports, comprehensive literature reviews, book reviews, and student research. 